be used, with the same stress cycle and a reasonably small power-input. It is later hoped to build an apparatus of greater load capacity than that which was on view.

In the pulsating pressure fatigue testing of welded joints in thick steel tubes, fluid pressures of many tons per square inch must be applied. A machine for this purpose, developed at the University of Bristol, was shown in use. A characteristic of the machine is the reduction of fluid volume to the greatest possible extent, whereby the energy stored at each pulsation may be reduced to low values.

Although the use of ultrasonic inspection for weld flaws may increase markedly in future thick welded constructions, it has first been necessary to achieve reliable calibration with regard to the strength of echoes. In this respect, the use of standard reference blocks was demonstrated, by means of which an apparatus may be quickly calibrated. Equal attention is now being given to attenuation of pulses by virtue of different surface contours in contact with the ultrasonic probes, in conjunction with various fluid coupling agents.

During the past year, experimental work on the brittle-fracture strengths of welded mild-steel plates has been continued with the 700-ton tension test rig, which was on view together with the fractured specimens. It is now believed that the role of residual stress in promoting fracture is better understood. While these stresses have no embrittling influence of themselves, it has been shown in the presence of a notched weld parallel to the direction of tension, and notch brittle parent material, that the static strengths of wide plates may be reduced to low values, such as are normally present in structures. When the residual stresses are removed, yield point stresses may be consistently sustained before fracture takes place. Thus, it is now believed that the beneficial effect of stress-relieving of welded structures may be more readily assessed.

\section{UNIVERSITY AFFAIRS IN GREAT BRITAIN, 1954-55}

CONTRARY to the past few years, the "Returns 1 from Universities and University Colleges in receipt of Treasury Grant for the Academic Year 1954-55", issued by the University Grants Committee*, show an increase of 1,103 in the number of full-time students ; the latest figure is 81,705 , compared with 80,602 in $1953-54,81,474$ in $1952-53$ and 83,458 in $1951-52$, and it is expected that the numbers in 1955-56 will show a further and greater increase, as it is known that there were 3,378 more full-time students in the autumn term of 1955 than in that of 1954. In the English universities, full-time men students increased by 395 and women by 500 ; for Wales, the corresponding figures were 46 and 17 ; and for Scotland, 61 and 84 . There were 4,987 fulltime and 2,010 part-time students from overseas within the British Commonwealth and 3,617 fulltime and 1,594 part-time students from foreign countries; for 1953-54 the corresponding figures were 4,607 and 1,819 for the Commonwealth and 3,373 and 1,379 for foreign countries. There was no

* Universities Grants Committee. Returns from Universities and University Colleges in Receipt of Treasury Grant for the Academic Year 1954-1955. (Cmd. 9800.) Pp. 50. (London: H.M.S.O., 1956.) 2s. $9 d$. significant change in the distribution of full-time students among the faculties; but there were small increases both for science and technology: from $21 \cdot 1$ to 21.2 per cent for the former, an increase from 16,971 to 17,327 , and from $12 \cdot 4$ to $12 \cdot 9$ per cent for the latter, an increase from 10,036 to 10,586. Full-time advanced students of pure science increased by 45 to 3,335 , those of technology by 74 to 1,455 , of agriculture by 17 to 307 , and of veterinary science by 6 to 18 , while those of medicine decreased by 49 to 813 . Of the full-time advanced students, 2,835 (or $23 \cdot 2$ per cent) were working for the teacher's diploma. Of the full-time students, 64,778 were reading for $a$ first degree, 4,099 for a first diploma and 12,212 were engaged in research or other advanced work, the corresponding figures for 1953-54 being $63,560,4,350$ and 12,166 .

The proportion of assisted students was 72.9 per cent compared with 71.9 per cent in 1953-54; for England as a whole it increased from 74.2 to 74.9 per cent, but for Scotland it increased from $56 \cdot 8$ to $59 \cdot 5$ per cent, and for Wales decreased from $88 \cdot 5$ to $86 \cdot 6$ per cent. The dependence on parliamentary grants was practically unchanged, the $£ 25,059,434$ received from this source representing 70.4 per cent of the total income compared with $70 \cdot 5$ per cent in 1953-54. Of the recurrent income, $10 \cdot 7$ per cent came from fees, $4 \cdot 1$ per cent from endowments, $3 \cdot 2$ per cent from local authority grants and $1 \cdot 1$ per cent from donations and subscriptions, the corresponding figures for 1953-54 being $12 \cdot 0,4 \cdot 3,3 \cdot 6$ and $1 \cdot 6$ per cent, respectively. Universities were asked to show separately for the first time in 1954-55 income from grants for research and income receivable under research contracts : for England the former amounted to $£ 1,079,307$ and the latter to $\mathfrak{1 6 8 5 , 6 1 5}$; for Wales the corresponding figures are $£ 17,787$ and $£ 8,213$, and for Scotland $£ 115,308$ and $£ 45,683$. The ratio of staff to students again improved, the full-time teaching staff being now 9,810, compared with 9,514 in 1953-54. The distribution of this increase among staff is : professors, 43 ; readers, assistant professors and independent lecturers, 36 ; senior lecturers, 4I; and lecturers, 176.

Of the full-time students, 63,068 were in England $(15,121$ at Oxford and Cambridge, 18,201 at London and 29,746 at other universities and university colleges), 4,494 in Wales and 14,143 in Scotland. Except at Liverpool and at Reading, where there were decreases of 1 and 10, respectively, the increase in students was distributed over all the universities and colleges, but only at Oxford (150), Southampton (137), Durham (139), Leeds (128), St. Andrews (114) and Cambridge (104) did the increase exceed a hundred, though the increase by 95 to 719 at the Manchester College of Technology was the highest proportionate increase. The proportion of full-time students residing in colleges and halls of residence increased to 28.4 per cent; and, of these 23,243 students, 8,262 were at Oxford and Cambridge, 11,838 at other English institutions and only 1,261 in Wales and 1,882 in Scotland. The proportion of men in residence was $24 \cdot 2$ per cent, and of women $41 \cdot 3$ per cent, while 34,548 students $(42 \cdot 3$ per cent) were in lodgings and $23,914(29 \cdot 3$ per cent) at home, compared with 40.9 per cent and $31 \cdot 0$ per cent, respectively, during the previous year. Of the 22,463 students admitted for the first time during 1954-55 (an increase of 1,310 on 1953-54), 20,946 were reading for a first degree and 1,517 for a first diploma; of those reading for a first degree, 1,233 
were under eighteen years of age and 11,843 were nineteen or more. Of the full-time students, 35,723 out of 47,793 men and 11,528 out of 15,275 women in England were receiving assistance by way of scholarships, exhibitions or other awards from public or private funds; for Wales the corresponding figures are 2,726 out of 3,187 men and 1,166 out of 1,307 women; and for Scotland, 6,331 out of 10,315 men and 2,089 out of 3,828 women. Of the 61,295 full-time men students, $36 \cdot 1$ per cent were in arts, $22 \cdot 3$ per cent in pure science, $16 \cdot 6$ per cent in medicine and 17.0 per cent in technology; for the 20,410 women students the corresponding figures are $63 \cdot 7,18 \cdot 0,14 \cdot 4$ and 0.7 per cent, respectively. Medicine and dentistry claimed 52.2 per cent of the part-time advanced students, arts 34.9 per cent, pure science $9 \cdot 2$ per cent and technology $2 \cdot 7$ per cent, compared with $49 \cdot 6,35 \cdot 6,9 \cdot 3$ and $4 \cdot 8$ per cent, respectively, during 1953-54.

The recurrent income of the universities and university colleges of Great Britain increased by $£ 4,488,054$ to $£ 35,600,078$, of which $£ 25,059,434$ was from parliamentary grants, $£ 3,815,306$ from fees, $£ 1,448,212$ from endowments, $£ 1,140,643$ from local authority grants and $£ 401,379$ from donations and subscriptions. Of the total income of $£ 26,200,007$ from public funds and $£ 9,400,001$ from other sources, the University of London received $£ 7,803,937$ and

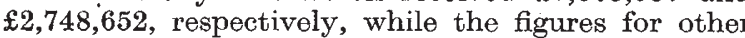
universities were Cambridge $£ 1,659,067$ and $£ 1,371,494$; Oxford, $£ 1,489,853$ and $£ 780,791$; Manchester, £1,293,893 and £321,976; Leeds, $£ 1,107,057$ and $£ 350,586$; Birmingham, $£ 1,069,933$ and $£ 438,788$; Durham, $£ 1,152,240$ and $£ 369,320$; Liverpool, $£ 1,057,395$ and $£ 320,826$; Bristol, $£ 825,567$ and $£ 430,386$; Sheffield, $£ 710,398$ and $£ 186,487$; Nottingham, $£ 568,488$ and $£ 148,410$; and Reading, $£ 624,686$ and $£ 93,438$. No other English university or university college had an income exceeding half a million pounds; but for the four universities in Scotland the incomes from public funds and from other sources were Aberdeen, $£ 576,117$ and $£ 138,690$; Edinburgh, $£ 1,235,533$ and $£ 415,402$; Glasgow, £1,229,990 and £397,244 ; and St. Andrews $£ 612,090$ and $£ 129,357$. The University of Wales, including the Welsh National School of Medicine, received $£ 1,326,200$ and $£ 336,405$.

Of the recurrent expenditure of $£ 34,791,656$, an increase of 15 per cent on 1953-54, administration accounted for 7.2 per cent, departmental maintenance $69 \cdot 3$ per cent, maintenance of premises $12 \cdot 0$ per cent, and miscellaneous expenditure $10 \cdot 2$ per cent. Departmental maintenance, which includes salaries of teaching staff, payments for superannuation, the running costs of laboratories, lecture rooms, libraries and museums, and the supply of books, specimens, materials, apparatus, etc., increased by $£ 2,095,004$ to $£ 24,100,985$ and expenditure on maintenance of buildings increased by 8.2 per cent. Salaries and superannuation amounted to $£ 15,958,695$, compared with $£ 13,616,426$ in $1953-54$, the increase being $17 \cdot 2$ per cent for teaching staff and 14.8 per cent for technicians and laboratory assistants.

Library expenditure, excluding general maintenance of library buildings, rates, heat, light, repairs, etc., amounted to $£ 1,352,244$, or $3 \cdot 8$ per cent of the total expenditure, compared with 4.0 per cent in 1953-54 and $3 \cdot 9$ per cent in 1952-53. Of this total, $£ 707,236$ was for salaries and wages, $£ 154,963$ on periodicals and $£ 101,885$ on bindings. Of the $£ 310,102$ expended on books, $£ 72,939$ was in the schools and colleges of the University of London, including $£ 12,192$ at the Central Library, $£ 6,183$ at the London School of Economies, $£ 9,273$ at University College, $£ 5,153$ at the School of Oriental and African Studies and $£ 4,909$ at Bedford College. The University of Oxford spent $£ 31,585$ on books ; Cambridge, $£ 22,796$; Manchester, £21,559 ; Liverpool, £11,608; Leeds, $£ 10,116$; Durham, $£ 12,993$; Birmingham, $£ 10,215$; and Bristol, $£ 9,553$. Only the Universities of London $(£ 44,813)$, Oxford $(£ 14,948)$ and Cambridge $(£ 12,233)$ spent more than $£ 10,000$ on periodicals, and only

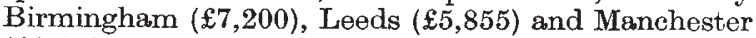
$(£ 6,458)$ more than $£ 5,000$. The University of Wales spent $£ 14,789$ on books and $£ 8,457$ on periodicals. In Scotland, Edinburgh spent $£ 15,087$ on books and $£ 6,813$ on periodicals ; Glasgow, $£ 11,662$ and $£ 7,382$; St. Andrews, $£ 11,856$ and $£ 4,702$; and Aberdeen, $£ 8,333$ and $£ 3,954$.

\section{INSTITUTE OF PHYSICS REPORT FOR 1955}

$T$ HE thirty-sixth annual report of the Board of the Institute of Physics*, which was presented to the annual meeting of the Institute in London on July 16, indicates the growing importance of the work of the Institute and the increasing number of physicists now being employed in industry, teaching and research. The total membership rose during the year under reviow by 397 to 5,146 , reaching the five thousand mark for the first time. There were increases in all the grades of membership, with substantial increases in the associateship and graduateship grades. 726 applications for election or transfer to the various grades were received during the year, compared with 579 during 1954. Eleven of the fifty-four candidates who took the examination for graduateship of the Institute were successful. The numbers of candidates for the final examinations for the National Certificate in Applied Physics were 309 for the ordinary level and $\mathbf{8 2}$ for the higher, compared with 206 and 75, respectively, in 1954.

The report mentions that representatives of the membership committee visited seven technical colleges which had applied for official recognition, or extension of recognition, by the Board as institutions suitable for training of physicists in accordance with the Institute's membership regulations. The degrees of the University of Malaya were also recognized by the Board. The report of an inquiry by the Board into the availability of places for students of physics in the universities and larger technical colleges of Great Britain was published by the Institute in its September Bulletin, and reprints have since been widely circulated. Many requests continue to be received from those leaving school and others concerning careers in physics, and the deputy secretary of the Institute, Mr. N. Clarke; has addressed meetings on this subject in Aberdeen, Bristol, Edinburgh, Ewell, Glasgow and Swansea. The Institute has kept in close and constant touch with the permanent officers of the American Institute of Physics and has made a joint inquiry with the Physical Society, London, about the likely demand for English translations of Russian papers on pure and applied physics.

* Thirty-sixth Annual Report of the Board of the Institute of Physics, 1955. Pp. 18. (London: Institute of Physics; 1956.) 